\title{
SPATIAL DYNAMICS OF SPECIES RICHNESS OF PHYTOPLANKTON OF LAKE BALKHASH IN THE GRADIENT OF ABIOTIC FACTORS
}

\author{
Sophia BARINOVA *, Elena KRUPA ** and Ulrika KADYROVA ***
}

* Institute of Evolution, University of Haifa, Mount Carmel, Abba Khoushi Avenue 199, Haifa, Israel, IL-3498838, sophia@evo.haifa.ac.il

** Republican State Enterprise on the Right of Economic Use "Institute of Zoology", Ministry of Education and Science, Science Committee, Almaty, Kazakhstan, KZ-050060, elena_krupa@mail.ru

*** "Kazakh Research Institute of Fishery" LLP, Zheltoksan Street 20, Balkhash, Kazakhstan, KZ-100300, ylirika@inbox.ru

DOI: 10.1515/trser-2017-0009

KEYWORDS: biodiversity, macrophytes, TDS, biogenes, heavy metals, Kazakhstan.

\section{ABSTRACT}

The spatial distribution of species richness of phytoplankton was studied along the Balkhash Lake water area during the summer of 2004. With statistically weak connections of phytoplankton with environmental parameters, three-dimensional graphs revealed a complex character of its spatial variability in the gradient of environmental factors. Macrophytes had a stimulating effect on the species richness of planktonic algae. We found a correlation between species richness of Cyanobacteria, Chrysophyta, Euglenophyta and Dinophyta and the ionic composition of water. The important role of temperature was traced. Species richness of algal communities increased with increasing temperature in the gradient of nutrients and correlated with the abundance of macrophytes.

ZUSAMMENFASSUNG: Die räumliche Dynamik der Artenvielfalt des Phytoplanktons im Balkhasch-See entlang der Gradienten abiotischer Faktoren.

Die räumliche Verteilung der Artenvielfalt des Phytoplanktons wurde im Sommer 2004 entlang des Balkhash-See-Gebiets untersucht. Bei statistisch schwachen Verbindungen von Phytoplankton mit Umweltparametern zeigten dreidimensionale Graphiken den komplexen Charakter ihrer räumlichen Variabilität im Gradienten der Umweltfaktoren. Makrophyten hatten eine stimulierende Wirkung auf den Artenreichtum der Planktonalgen. Gezeigt wird in vorliegender Arbeit die Korrelation zwischen Artenreichtum von Cyanobakterien, Chrysophyta, Euglenophyta und Dinophyta und der ionischen Zusammensetzung des Wassers. Verfolgt wurde auch die wichtige Rolle des Temperaturfaktors. Der Artenreichtum der Algengemeinschaften nahm mit zunehmender Temperatur entlang des Nährstoffgradienten und in Korrelation mit der MakrophytenAbundanz zu.

REZUMAT: Dinamica spațială a bogăţiei speciilor de fitoplancton din lacul Balkhash în corelaţie cu gradientul factorilor abiotici.

Distribuția spațială a bogăției speciilor de fitoplancton a fost studiată de-a lungul lacului Balkhash în vara anului 2004. Cu conexiuni slabe statistic ale fitoplanctonului cu parametrii de mediu, graficele tridimensionale au relevat un caracter complex al variabilității spațiale în gradientul factorilor de mediu. Macrofitele au un efect stimulator asupra bogăției speciilor de alge planctonice. Există o corelație între bogăția de specii de cianobacterii, Chrysophyta, Euglenophyta și Dinophyta și concentraţia ionilor în apă. A fost evidenţiat şi rolul important al temperaturii în structurarea comunităţilor de alge planctonice. Bogăţia în specii a comunităţilor de alge creşte odată cu creşterea temperaturii apei, cu cantitatea de nutrienţi din apă şi se corelează cu abundenţa macrofitelor. 


\section{INTRODUCTION}

Lake Balkhash (Figs. 1-3) (south-east of Kazakhstan) runs from the south-west to the nort-heast. At surface level, it is $342 \mathrm{~m}$ maximum depth, $614 \mathrm{~km}$ long and covers an area of approximately 16.4 thousand $\mathrm{km}^{2}$ (Kudekov, 2002). The Uzun-Aral Strait divides the lake into two parts - the Western and Eastern Balkhash. The food is provided by the rivers Ily, Karatal, Aksu, Lepsy, originating in the mountains of the Tien Shan in the zone of glaciers and flows into the lake from the south. The peculiarity of Balkhash is the growth of the total content of dissolved salts along the longitudinal axis, in connection with which its water area is divided into eight hydrochemical regions (Fig. 1) (Tarasov, 1961).

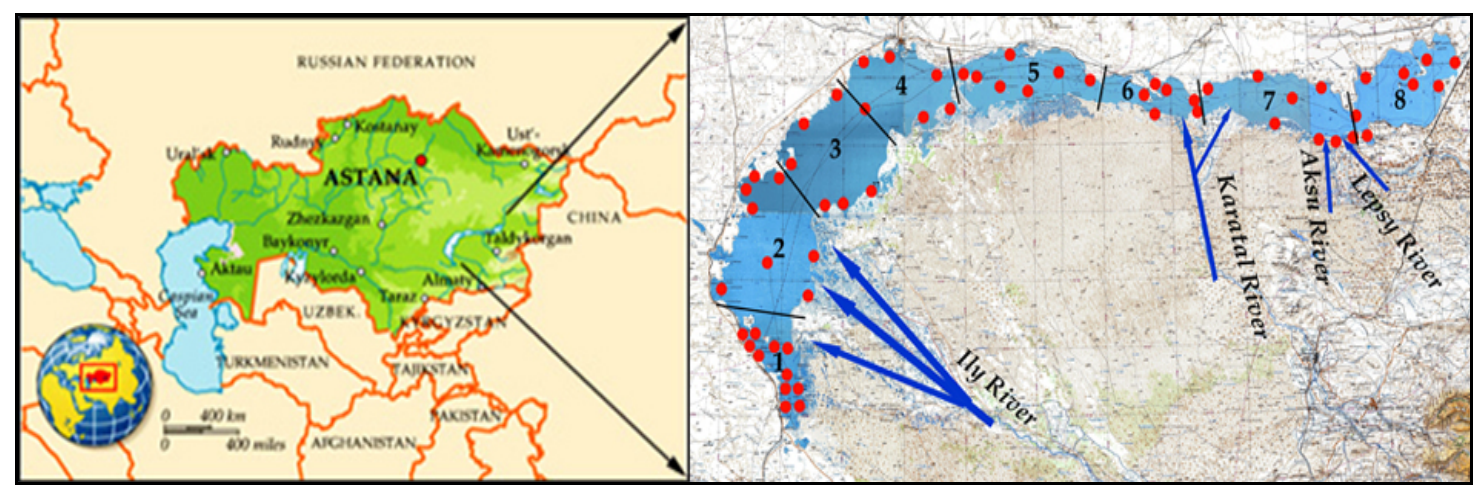

Figure 1: Lake Balkhash sampling stations map in 2004; blue arrow are the river water input, 1-8 are hydrochemical regions.

The average value of TDS in different years varies from $0.60-1.20 \mathrm{~g} \mathrm{dm}^{-3}$ in the west to 4.04-5.60 $\mathrm{g} \mathrm{dm}^{-3}$ in the east (Kudekov, 2002). The lake is located in an area with large deposits of polymetallic ores (Mazurov, 2005), which are responsible for the increased background levels of heavy metals in the water and soil. Technogenic pollution of Balkhash Lake and adjacent territories is due to industrial extraction and processing of minerals (Samakova, 2003). The significant heterogeneity of abiotic factors affects the spatial distribution of phytoplankton as the primary trophic level of any aquatic ecosystem.

Systematic studies of phytoplankton in lake Balkhash have been carried out since 1971. The focus has been the study of the species composition of planktonic and benthic algae (Akhmetova, 1986), the identification of dominant species, and the assessment of the level of feeding in the hydrochemical regions of the lake (Abrosov, 1973; Vorobyeva et al., 1982; Fokina, 1982; Ponomareva et al., 2005) in relation to climatic factors (Krupa et al., 2014).

The aim of this work is to study the spatial distribution of species richness of phytoplankton in the water area of lake Balkhash in the gradient of hydrophysical, hydrochemical and toxicological factors. 


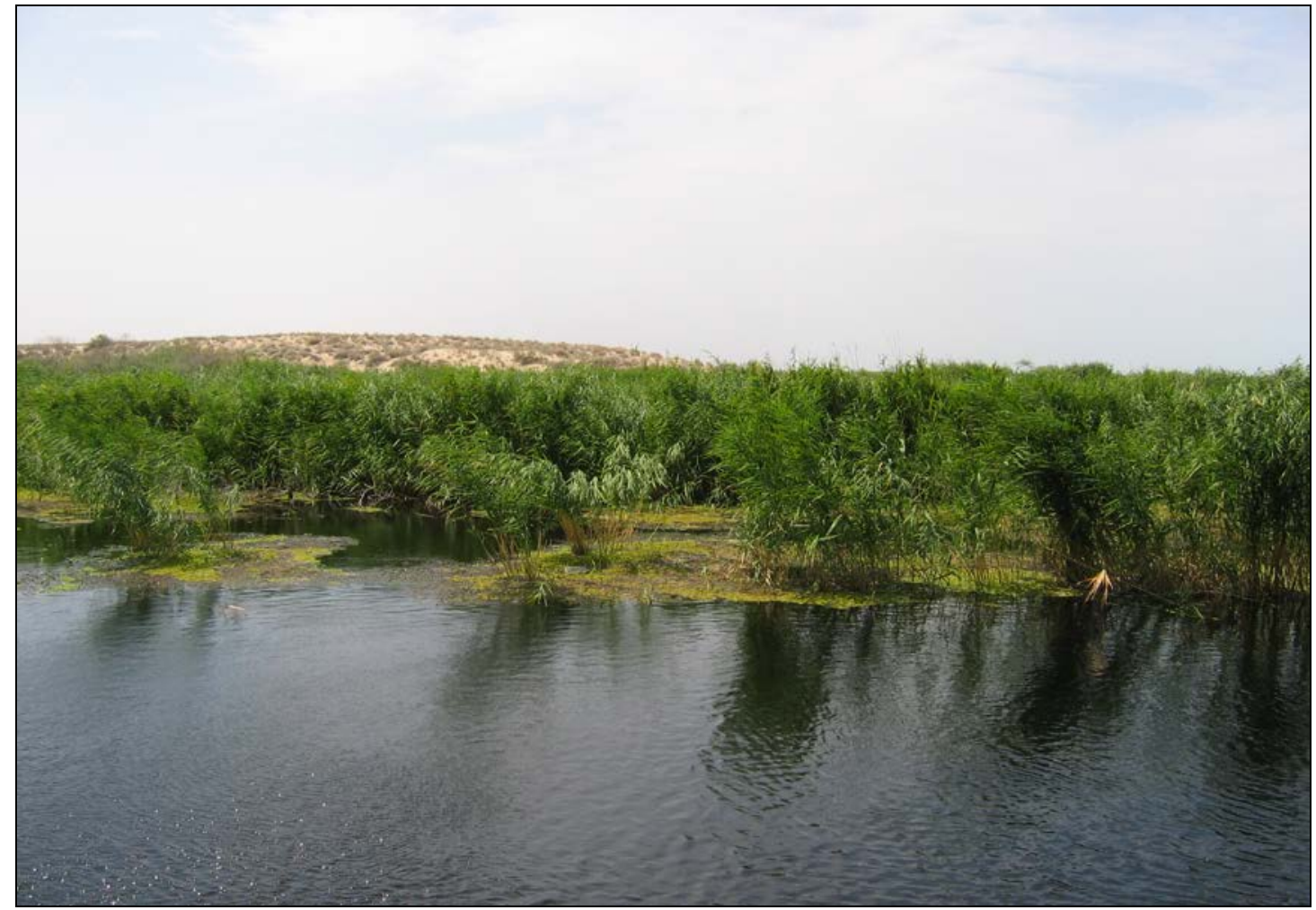

Figure 2: Eastern Balkhash Lake.

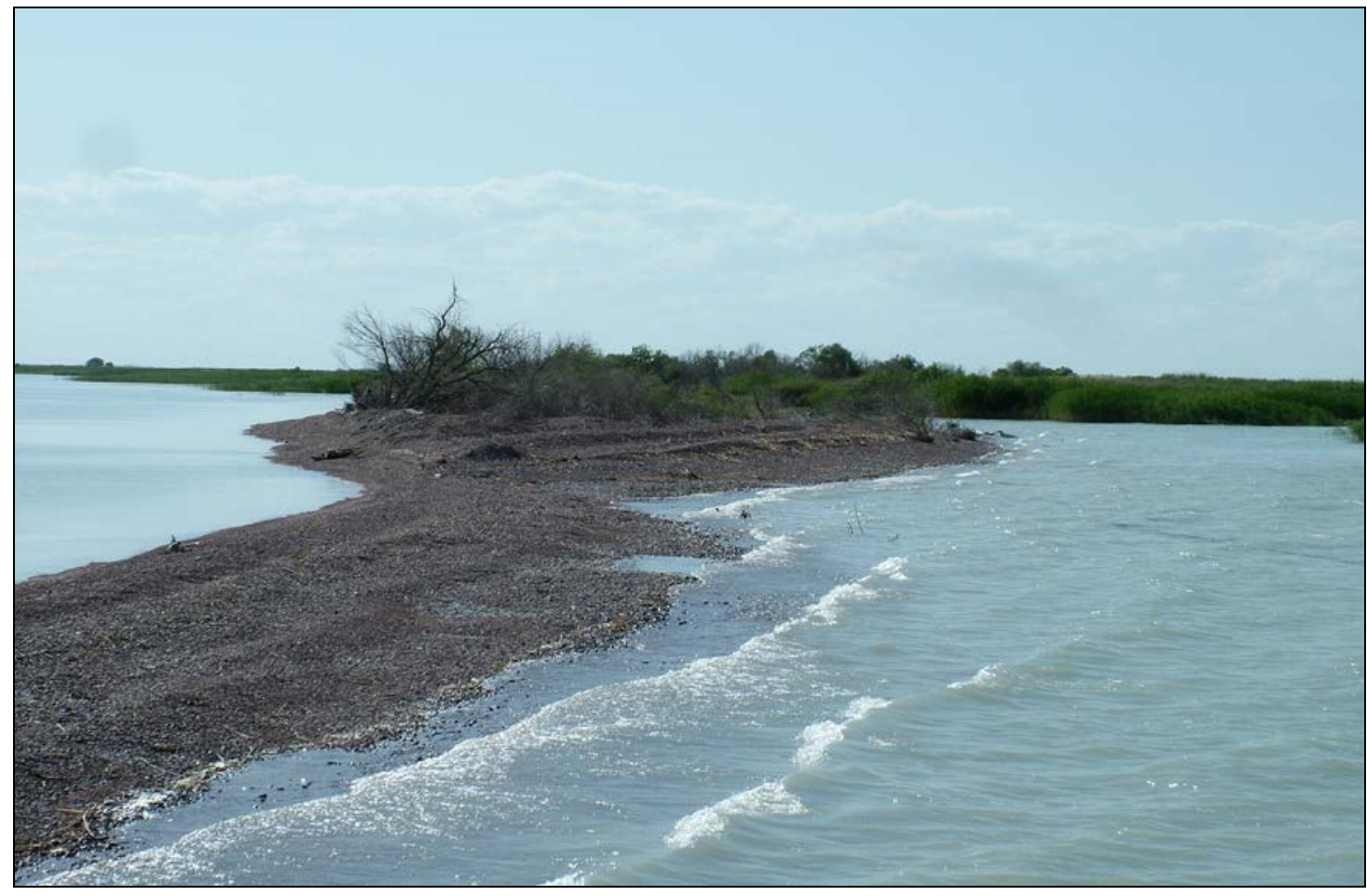

Figure 3: Western Balkhash Lake. 


\section{MATERIAL AND METHODS}

The research of phytoplankton and total dissolved solids (TDS) content was carried out by means of a grid of 58 stations (Fig. 1) in June and July of 2004. The measures of the temperature and $\mathrm{pH}$ values of the surface water layers were taken in the field environment. Water transparency was measured with a Secchi disk. Coordinate referencing of the stations was done by Garmin eTrex GPS-navigator. The samples for heavy metals were fixed in the site by adding nitric acid; samples for biogenes were fixed with chloroform. All collected samples were transported to the lab in an icebox.

Conventional methods of chemical analysis of water were used (Semenova, 1977; Fomin, 1995). Water samples were analyzed in three-four replications. The error of estimate for major ions in the water was $0.5-5.0 \%$, depending on the analyte. Heavy metal measuring was performed by mass spectrometry with inductively coupled plasma by using Agilent 7500 A manufactured by Agilent Technologies, USA (National Standard RK ISO 17294-2-2006). The device allows for the detection of the various chemical elements in complex matrices, including those in the sea and grey water and in the biological objects in micro-trace quantities. Abundance Sensitivity of Agilent 7500 A: Low Mass $<5 \times 10^{-7}$, High Mass $<1 \times 10^{-7}$.

For the processing of phytoplankton samples, the settling method was used (Kiselev, 1956). Species identification of planktonic algae was performed by using determinants for relevant divisions (Zabelina et al., 1951; Gollerbach et al., 1953; Popova, 1955; Palamar-Mordvintseva, 1982; Moshkova and Gollerbach, 1986). The statistical methods were implemented in the GRAPHS program (Novakovsky, 2004) used for the comparative floristics and Statistica 12.0 for nonparametric correlation analysis, spatial mapping innovative approach and surface plots' construction in analysis of biological and environmental variables' relationship.

The integral index of aquatic ecosystem sustainability (WESI) was constructed on results of our studies (Barinova et al., 2006). It is based on the water quality ranges as determined by saprobity indices $S$ and nitrate (or phosphates) concentrations. The resulting WESI index reflects the self-purification capacities of the aquatic ecosystem. At WESI $\geq 1$, the photosynthetic level is positively correlated with the level of nitrate concentration. At WESI $<1$, photosynthesis is suppressed (presumably due to a toxic disturbance) if the water body is slightly contaminated by toxicants.

\section{RESULTS}

The Western and Eastern Balkhash Lake significantly differ in their characteristics, as can be seen in table 1. The western part of the lake is shallow, with less transparency, lower water $\mathrm{pH}$, and less spread of hard macrophytes, but greater water coverage by soft macrophytes. The deeper and narrower eastern part of the water area is overgrown with hard and soft macrophytes to approximately the same degree. The hard macrophytes are represented by Phragmites australis (Cav.) Trin. ex Steud., Schoenoplectus lacustris (L.) Palla; the soft macrophytes by Potamogeton críspus L., Stuckenia pectinata (L.) Böerner, Nymphaea sp., Nuphar sp., Myriophyllum spicátum L., Ceratophyllum sp., as well as the charophytic macroalgae Chara tomentosa Linnaeus and Nitellopsis obtusa (Desvaux) Groves. Macrophytes develop mainly near the southern and southeastern shores of the lake, in shallow-water zones under the influence of river flow (Fig. 4). 
Table 1: Hydrophysical and morphometric characteristics of the lake Balkhash, summer 2004.

\begin{tabular}{|l|c|c|c|}
\hline \multicolumn{1}{|c|}{ Variable } & $\begin{array}{c}\text { Whole } \\
\text { Balkhash Lake }\end{array}$ & $\begin{array}{c}\text { Western } \\
\text { Balkhash Lake }\end{array}$ & $\begin{array}{c}\text { Eastern } \\
\text { Balkhash Lake }\end{array}$ \\
\hline Temperature $\left({ }^{\circ} \mathrm{C}\right)$ & $24.14 \pm 0.14$ & $23.49 \pm 0.16$ & $24.77 \pm 0.14$ \\
\hline Depth $(\mathrm{m})$ & $5.58 \pm 0.49$ & $4.34 \pm 0.28$ & $6.86 \pm 0.81$ \\
\hline Transparency (m) & $1.13 \pm 0.15$ & $0.53 \pm 0.02$ & $1.74 \pm 0.25$ \\
\hline Macrophytes hard (\%) & $20.05 \pm 3.03$ & $18.03 \pm 3.00$ & $22.14 \pm 5.36$ \\
\hline Macrophytes soft (\%) & $25.18 \pm 2.68$ & $28.28 \pm 3.29$ & $22.00 \pm 4.24$ \\
\hline pH & $8.63 \pm 0.04$ & $8.52 \pm 0.02$ & $8.74 \pm 0.09$ \\
\hline
\end{tabular}

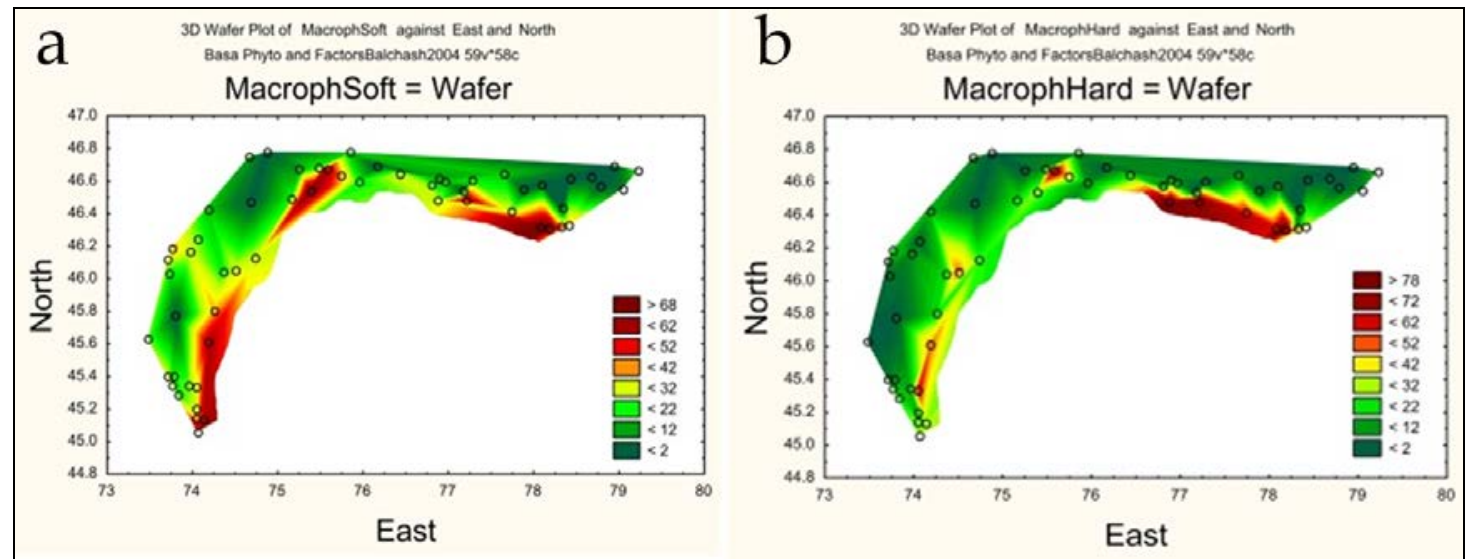

Figure 4: Distribution of soft and hard macrophytes along lake Balkhash, summer 2004.

The TDS of the East Balkhash water was statistically significantly higher than in the western part during the summer of 2004 (Tab. 2). The ionic composition was dominated by sulphates and sodium. The total content of dissolved solids in the water increased in the direction from west to east, with a simultaneous increase in the concentration of all ions except calcium. Higher concentrations of nitrates, nitrites, total phosphorus, iron, zinc, and copper are found in Western Balkhash water. Phosphates, readily oxidized organic matter, cadmium, lead, nickel and cobalt were present in large quantities in the water of the eastern part of the water area. The content of ammonia and silicon did not differ in the two parts of the lake.

The revealed phytoplankton was represented by 91 species, of which greens 29, diatoms 26, cyanobacteria 21, charophytes four, euglenophytes four, dinophytes three, and chrysophytes one. No more than 7-15 species were represented in algal communities in most of the water area, as a general rule. In Western Balkhash, where Chlorophyta prevailed (Fig. 5a), the number of species of plankton algae (74) was higher than in Eastern Balkhash (69), where the basis of species richness was formed by Bacillariophyta. In Western Balkhash, the most frequently encountered dinophyte Peridinium sp., diatom Cyclotella meneghiniana Kützing, and euglenophyte Trachelomonas sp. In Eastern Balkhash, in addition to the last two species, diatom Navicula sp., green alga Franceia sp., and cyanobacteria species Snowella lacustris (Chodat) Komárek and Hindák, Gomphosphaeria aponina Kützing and Gloeocapsa sp. were represented. Species composition of algae underwent changes in the hydrochemical regions of the lake (Fig. 5c), with an increase in the species richness of cyanobacteria and a decrease in the number of species of euglenoic, chrysophytes and dinophytes, as a response to changes in the ionic composition of the lake water. 
The hydrochemical regions' communities of the lake were divided into three clusters at the similarity level of the species composition of planktonic algae more than 50\% (Fig. 6a). The first cluster united the phytoplankton species of the greater part of Western Balkhash (hydrochemical regions 1, 2, and 4). The second cluster included communities of Eastern Balkhash, except for the 7th region, and algal communities of the 3rd hydrochemical region of the western part. An area with a unique species composition of planktonic algae was the 7th hydrochemical region, which separated into a different cluster.

Table 2: Total Dissolved Solids (TDS), hydrochemical water variables and toxicants of Balkhash Lake, summer 2004; all variables in $\mathrm{mg} \mathrm{dm}^{-3}$, oxidability in $\mathrm{mg}_{2} \mathrm{dm}^{-3}$.

\begin{tabular}{|c|c|c|c|}
\hline *Variable & $\begin{array}{c}\text { Whole } \\
\text { Balkhash Lake }\end{array}$ & $\begin{array}{c}\text { Western } \\
\text { Balkhash Lake }\end{array}$ & $\begin{array}{c}\text { Eastern } \\
\text { Balkhash Lake }\end{array}$ \\
\hline $\mathrm{Ca}$ & $40.4 \pm 2.5$ & $48.8 \pm 4.4$ & $32.4 \pm 1.3$ \\
\hline $\mathrm{Mg}$ & $67.4 \pm 6.6$ & $35.0 \pm 2.2$ & $98.4 \pm 8.4$ \\
\hline $\mathrm{Na}+\mathrm{K}$ & $454.8 \pm 53.8$ & $202.6 \pm 22.9$ & $695.6 \pm 71.8$ \\
\hline $\mathrm{HCO}_{3}$ & $415.1 \pm 31.6$ & $254.3 \pm 11.0$ & $568.6 \pm 38.6$ \\
\hline $\mathrm{SO}_{4}$ & $834.9 \pm 93.1$ & $369.1 \pm 344$ & $1,279.5 \pm 116.2$ \\
\hline $\mathrm{Cl}$ & $473.3 \pm 58.9$ & $170.5 \pm 18.6$ & $762.4 \pm 71.3$ \\
\hline TDS & $2,286.0 \pm 2,36.0$ & $1,080.3 \pm 83.4$ & $3,436.8 \pm 286.7$ \\
\hline $\mathrm{Na}$ & $448.9 \pm 51.1$ & $193.8 \pm 2.2$ & $692.4 \pm 63.3$ \\
\hline K & $30.4 \pm 4.1$ & $8.8 \pm 1.0$ & $51.0 \pm 4.9$ \\
\hline $\mathrm{K} / \mathrm{Na}$ & $0.063 \pm 0.004$ & $0.046 \pm 0.0009$ & $0.080 \pm 0.005$ \\
\hline $\mathrm{K} / \mathrm{Ca}$ & $0.978 \pm 0.161$ & $0.196 \pm 0.022$ & $1.725 \pm 0.215$ \\
\hline $\mathrm{Mg} / \mathrm{Ca}$ & $2.021 \pm 0.256$ & $0.749 \pm 0.039$ & $3.235 \pm 0.331$ \\
\hline $\mathrm{NH}_{4}$ & $0.102 \pm 0.017$ & $0.103 \pm 0.013$ & $0.102 \pm 0.033$ \\
\hline $\mathrm{NO}_{3}$ & $0.945 \pm 0.244$ & $1.379 \pm 0.410$ & $0.492 \pm 0.226$ \\
\hline $\mathrm{NO}_{2}$ & $0.042 \pm 0.011$ & $0.060 \pm 0.013$ & $0.024 \pm 0.016$ \\
\hline $\mathrm{P}-\mathrm{PO}_{4}$ & $0.017 \pm 0.004$ & $0.011 \pm 0.003$ & $0.023 \pm 0.007$ \\
\hline $\mathrm{P}_{\text {tot }}$ & $0.064 \pm 0.001$ & $0.106 \pm 0.012$ & $0.021 \pm 0.007$ \\
\hline $\mathrm{Fe}$ & $0.032 \pm 0.005$ & $0.056 \pm 0.006$ & $0.010 \pm 0.0006$ \\
\hline $\mathrm{Si}$ & $5.49 \pm 0.15$ & $5.20 \pm 0.22$ & $5.76 \pm 0.20$ \\
\hline Oxidability & $7.39 \pm 0.46$ & $5.07 \pm 0.40$ & $9.13 \pm 0.45$ \\
\hline $\mathrm{Zn}$ & $0.028 \pm 0.009$ & $0.039 \pm 0.018$ & $0.017 \pm 0.002$ \\
\hline $\mathrm{Cu}$ & $0.018 \pm 0.003$ & $0.022 \pm 0.005$ & $0.013 \pm 0.002$ \\
\hline $\mathrm{Cd}$ & $0.0036 \pm 0.0002$ & $0.0028 \pm 0.0002$ & $0.0044 \pm 0.0002$ \\
\hline $\mathrm{Pb}$ & $0.034 \pm 0.003$ & $0.021 \pm 0.002$ & $0.047 \pm 0.004$ \\
\hline $\mathrm{Ni}$ & $0.039 \pm 0.001$ & $0.037 \pm 0.002$ & $0.042 \pm 0.002$ \\
\hline Co & $0.013 \pm 0.001$ & $0.010 \pm 0.0005$ & $0.017 \pm 0.001$ \\
\hline
\end{tabular}

The dendrite of species composition similarity, constructed by the Ward method, singled out the communities of the 3rd hydrochemical region as a core, which include the largest number of species from other parts of the water area (Fig. 6b). Phytoplankton of the 3rd region, in turn, were close to the algal communities of the 1st region, the latter being the floristic core for the entire lake. 
The nonparametric correlation analysis revealed the presence of predominantly weak and moderate in strength relationships between abiotic factors and spatial dynamics of algae species richness (Tab. 3). The total number of species in algal communities increased with macrophytes growing in shallow water areas, with an increase in $\mathrm{K} / \mathrm{Na}$ values and a decrease in the concentrations of nitrites, copper and total toxic pollution expressed by the WESI index. The dynamics of the species number in the gradient of environmental parameters was generally similar, with some additional features. In addition to the factors listed above, table 3 show that Chrysophyta was affected by a reduction in the species number in response to an increase in cobalt and lead, Bacillariophyta for total phosphorus, and Cyanobacteria for calcium and iron increasing. Euglenophyta had a positive relationship with calcium, but showed a negative dependence on chloride. Cyanobacteria, in contrary, showed a negative relationship with nitrites, nitrates, total phosphorus, and calcium and a positive relationship with all other ions and total dissolved solids. The tendency with statistically weak connections is an increase in the total number of species of algae of macrophytes in shallow heated waters.

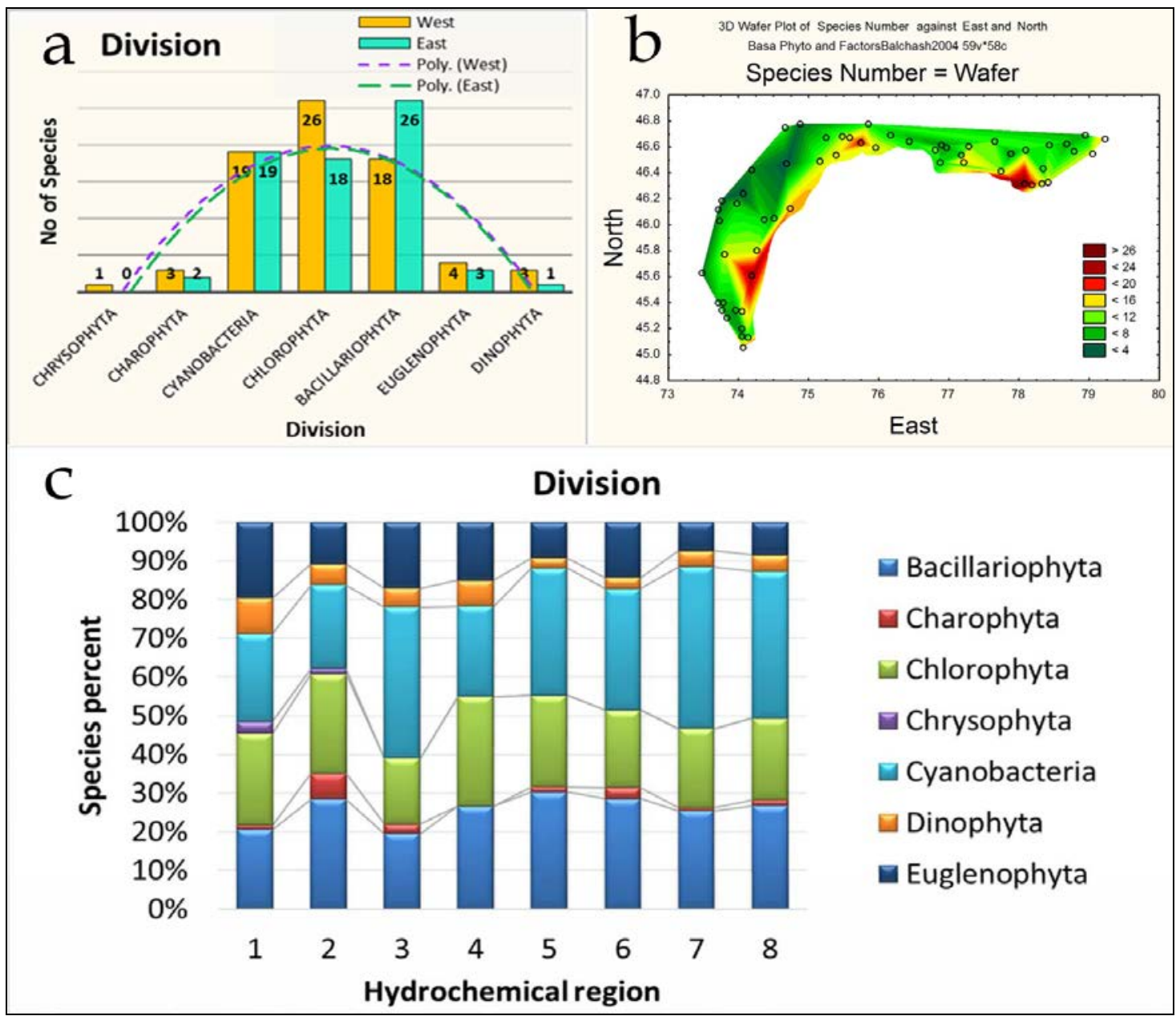

Figure 5: Distribution of phytoplankton species richness taxonomic division in the western and eastern part (a), water surface (b), hydrochemical regions (c) of lake Balkhash, summer 2004. 


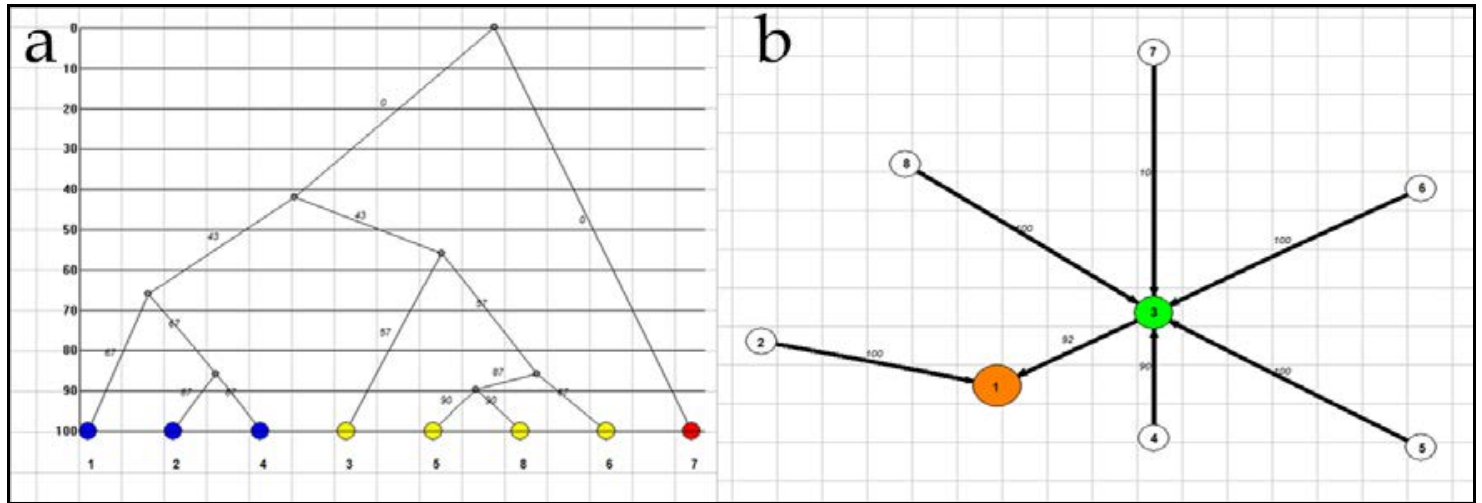

Figure 6: Dendrogram and dendrite similarities in species composition of phytoplankton in the hydrochemical regions of lake Balkhash, summer 2004.

The maps showed that local outbreaks of the species richness of phytoplankton (Fig. 5b) were confined to the southeastern and southern shores of the lake, i.e., to the areas of the aquatic area that overgrew macrophytes (Fig. 4). The tendency to increase the species richness of algal communities in connection with macrophytes was most clearly seen on 3d Surface Plots. With an almost linear increase in the number of algal species in the gradient of temperature and overgrowing by soft macrophytes (Fig. 7e), the connection with hard macrophytes was nonlinear (Fig. 7f). The tendency to increase the number of species of plankton algae with decreasing depth and rising water temperature (Fig. 7b) indirectly reflected the connection with macrophytes, confined to shallow, well-warmed areas of the lake. The leading role of the temperature factor in the formation of the species richness of algal communities was also traced in combination with the $\mathrm{pH}$ and water transparency (Figs. 7c, d).

The relationship between the species richness of phytoplankton and TDS, and the chemical composition of water was complex (Fig. 8), with general trends in the variability of the number of species depending on specified environmental parameters. Species richness of algae almost linearly increased in the gradient of calcium concentrations and temperature (Fig. 8a). The algal communities were represented by the maximum number of species at high temperatures and low concentrations of potassium (Fig. 8b), sodium (Fig. 8c), sulphates (Fig. 8f), chlorides (Fig. 8g), TDS (Fig. 8h) and the entire range of magnesium concentrations (Fig. 8d). The variability of the number of species under low-temperature conditions was nonlinear in the gradient of potassium, sodium, and TDS, with a second, less pronounced peak in the gradient of carbonates, and chlorides.

The algal communities of the lake showed a relative linear increase in the species number at maximum temperatures in the gradient of iron, ammonium, and nitrates (Figs. 9a, b, d). The relationship of the communities species richness with nitrites (Fig. 9c), the content of the easily oxidizable organic matter (Fig. 9e) and, partialy, with the total phosphorus (Fig. 7g) was nonlinear, and with phosphate was absent (Fig. 9f). The maximum of species richness is in the heated areas of the water surface, but with a low content of silicon in water (Fig. 9h).

The 3d Surface Plots revealed a rather complex character of the variability of the total number of algal species in the gradient of heavy metal concentrations (Fig. 10). The greatest phytoplankton species richness was observed in the warmest areas of the water surface where there were high concentrations of cobalt, copper, and nickel (Figs. 10b, c, d), and in the entire range of lead concentration (Fig. 10e). The effect of cadmium (Fig. 10a) and zinc (Fig. 10f) on the number of planktonic species of algae was manifested only locally. 
Table 3: The coefficients of Spearman Rank Order Correlations between the abiotic characteristics and the phytoplankton in Balkhash Lake, summer 2004, p $<0.05$.

\begin{tabular}{|c|c|c|c|c|c|}
\hline $\begin{array}{c}\text { Paired } \\
\text { variables }\end{array}$ & $\begin{array}{c}\text { Spearman } \\
\text { Rank } \\
\text { Order } \\
\text { Correlations }\end{array}$ & $\begin{array}{c}\text { Paired } \\
\text { variables }\end{array}$ & $\begin{array}{c}\text { Spearman } \\
\text { Rank } \\
\text { Order } \\
\text { Correlations } \\
\end{array}$ & $\begin{array}{c}\text { Paired } \\
\text { variables }\end{array}$ & $\begin{array}{c}\text { Spearman } \\
\text { Rank } \\
\text { Order } \\
\text { Correlations }\end{array}$ \\
\hline $\begin{array}{l}\text { Bacillariophyta - } \\
\text { Depth }\end{array}$ & -0.331 & $\begin{array}{l}\text { Cyanobacteria } \\
-\mathrm{HCO}_{3}\end{array}$ & 0.501 & $\begin{array}{ll}\text { Dinophyta } & - \\
\mathrm{Na} & \\
\end{array}$ & -0.353 \\
\hline $\begin{array}{l}\text { Bacillariophyta - } \\
\text { K/Na }\end{array}$ & 0.314 & $\begin{array}{l}\text { Cyanobacteria } \\
-\mathrm{K}\end{array}$ & 0.472 & $\begin{array}{ll}\text { Dinophyta } & - \\
\mathrm{SO}_{4} & \\
\end{array}$ & -0.315 \\
\hline $\begin{array}{l}\text { Bacillariophyta - } \\
\text { MacrophHard }\end{array}$ & 0.338 & $\begin{array}{l}\text { Cyanobacteria } \\
-\mathrm{K} / \mathrm{Ca}\end{array}$ & 0.496 & $\begin{array}{l}\text { Dinophyta }- \\
\text { TDS }\end{array}$ & -0.342 \\
\hline $\begin{array}{l}\text { Bacillariophyta - } \\
\text { MacrophSoft }\end{array}$ & 0.356 & $\begin{array}{l}\text { Cyanobacteria } \\
-\mathrm{K} / \mathrm{Na} \\
\end{array}$ & 0.513 & $\begin{array}{l}\text { Euglenophyta } \\
-\mathrm{Ca}\end{array}$ & 0.375 \\
\hline Bacillariophyta $-\mathrm{NO}_{2}$ & -0.397 & $\begin{array}{l}\text { Cyanobacteria } \\
-\mathrm{Mg}\end{array}$ & 0.453 & $\begin{array}{l}\text { Euglenophyta } \\
-\mathrm{Cl}\end{array}$ & -0.308 \\
\hline Bacillariophyta - Ptot & -0.319 & $\begin{array}{l}\text { Cyanobacteria } \\
-\mathrm{Na}\end{array}$ & 0.458 & $\begin{array}{l}\text { Euglenophyta } \\
\text { - Depth }\end{array}$ & -0.420 \\
\hline $\begin{array}{l}\text { Bacillariophyta - } \\
\text { Temperature }\end{array}$ & 0.311 & $\begin{array}{l}\text { Cyanobacteria } \\
-\mathrm{Na}^{+} \mathrm{K}\end{array}$ & 0.511 & $\begin{array}{l}\text { Euglenophyta } \\
\text { - MacrophSoft }\end{array}$ & 0.337 \\
\hline $\begin{array}{l}\text { Charophyta - WESI } \\
\mathrm{P}_{2} \mathrm{PO}_{4}\end{array}$ & 0.309 & $\begin{array}{l}\text { Cyanobacteria } \\
-\mathrm{SO}_{4}\end{array}$ & 0.413 & $\begin{array}{l}\text { Euglenophyta } \\
-\mathrm{Na}\end{array}$ & -0.303 \\
\hline $\begin{array}{l}\text { Charophyta - } \\
\text { MacrophSoft }\end{array}$ & 0.327 & $\begin{array}{l}\text { Cyanobacteria } \\
\text { - TDS }\end{array}$ & 0.469 & $\begin{array}{l}\text { Euglenophyta } \\
-\mathrm{Na}^{+} \mathrm{K}\end{array}$ & -0.377 \\
\hline $\begin{array}{l}\text { Chlorophyta - } \\
\text { MacrophHard }\end{array}$ & 0.337 & $\begin{array}{l}\text { Cyanobacteria } \\
-\mathrm{NO}_{2}\end{array}$ & -0.535 & $\begin{array}{l}\text { Euglenophyta } \\
-\mathrm{NH}_{4}\end{array}$ & 0.424 \\
\hline $\begin{array}{l}\text { Chlorophyta - WESI } \\
\text { P_PO }_{4}\end{array}$ & 0.600 & $\begin{array}{l}\text { Cyanobacteria } \\
-\mathrm{NO}_{3}\end{array}$ & -0.349 & $\begin{array}{l}\text { Species } \\
\text { Number } \\
\text { Depth }\end{array}$ & -0.452 \\
\hline Chrysophyta - Cl & -0.348 & $\begin{array}{l}\text { Cyanobacteria } \\
\text { - Ptot }\end{array}$ & -0.467 & $\begin{array}{l}\text { Species } \\
\text { Number - } \\
\text { MacrophHard }\end{array}$ & 0.489 \\
\hline Chrysophyta - Co & -0.409 & $\begin{array}{l}\text { Cyanobacteria } \\
\text { - Temperature }\end{array}$ & 0.465 & $\begin{array}{l}\text { Species } \\
\text { Number - } \\
\text { MacrophSoft }\end{array}$ & 0.420 \\
\hline Chrysophyta - Fe & 0.390 & $\begin{array}{l}\text { Cyanobacteria } \\
- \\
\text { Transparency }\end{array}$ & 0.368 & $\begin{array}{l}\text { Species } \\
\text { Number - } \\
\text { Temperature } \\
\end{array}$ & 0.349 \\
\hline Chrysophyta - Pb & -0.431 & $\begin{array}{l}\text { Cyanobacteria } \\
- \text { WESI NO }\end{array}$ & 0.508 & $\begin{array}{l}\text { Species } \\
\text { Number } \\
\mathrm{NO}_{2}\end{array}$ & -0.407 \\
\hline Cyanobacteria - Ca & -0.465 & $\begin{array}{l}\text { Cyanobacteria } \\
- \text { WESI NO } \\
\end{array}$ & 0.508 & $\begin{array}{l}\text { Species } \\
\text { Number - Ptot } \\
\end{array}$ & -0.346 \\
\hline Cyanobacteria-Cd & 0.498 & $\begin{array}{l}\text { Dinophyta }- \\
\mathrm{Cl}\end{array}$ & -0.366 & $\begin{array}{l}\text { Species } \\
\text { Number } \\
\text { K/Na } \\
\end{array}$ & 0.466 \\
\hline Cyanobacteria - Cl & 0.481 & $\begin{array}{ll}\text { Dinophyta } & - \\
\mathrm{HCO}_{3} & \\
\end{array}$ & -0.356 & $\begin{array}{l}\text { Species } \\
\text { Number - Cu }\end{array}$ & -0.405 \\
\hline Cyanobacteria $-\mathrm{Cu}$ & -0.552 & Dinophyta - K & -0.363 & $\begin{array}{l}\text { Species } \\
\text { Number - WE } \\
\text { SI P_PO }_{4}\end{array}$ & 0.453 \\
\hline Cyanobacteria - Fe & -0.591 & $\begin{array}{l}\text { Dinophyta }- \\
\text { K/Ca }\end{array}$ & -0.323 & $\begin{array}{l}\text { Species } \\
\text { Number } \\
\text { WESI NO }_{3}\end{array}$ & 0.424 \\
\hline
\end{tabular}


3D Surface Plot of TDS against Temper and pH
Basa Phyto and FactorsBalchash2 $200459 v^{5} 58 \mathrm{c}$

TDS $=$ Distance Weighted Least Squares

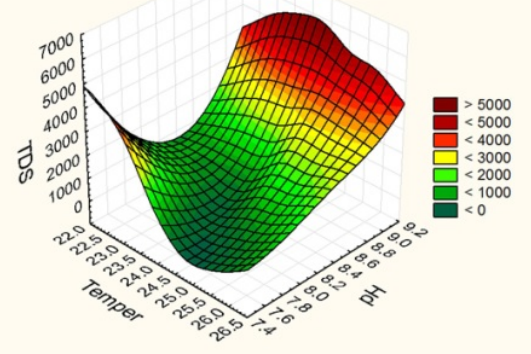

3D Surface Plot of Species Number against $\mathrm{pH}$ and Temper

C Species Number $=$ Distance Weighted Least Squares

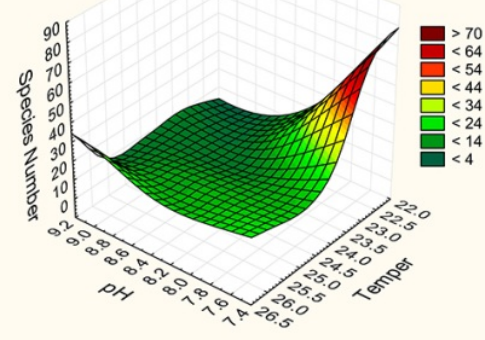

30 Surface Plot of Species Number against MacrophSoft and Temper
Basa Phyto and FactorsBalchash2004 59v*58c

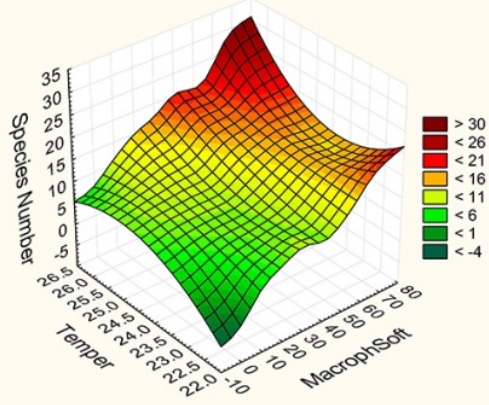

3D Surface Plot of Species Number against Depth and Temper Basa Phyto and FactorsBalchash $200459 v^{*} 58 \mathrm{c}$
Species Number $=$ Distance Weighted Least Squares

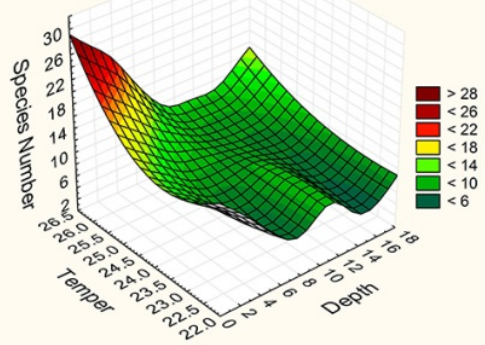

d

30 Surface Plot of Species Number against Transp and Temper Basto and FactorsBalchash2004 59v'58 Species Number $=$ Distance Weighted Least Squares

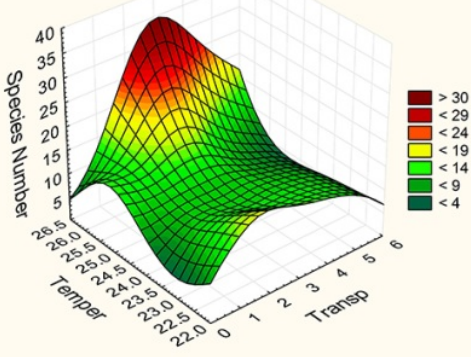

$3 D$ Surface Plot of Species Number against MacrophHard and Temper
Basa Phyto and FactorsBalchash2004 59 I Species Number $=$ Distance Weighted Least Squares

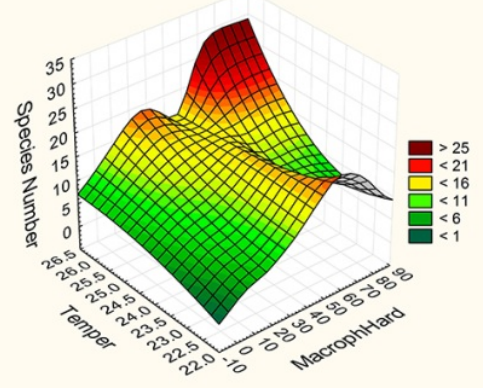

Figure 7: Distribution of species richness of phytoplankton depending on the hydrophysical factors of Lake Balkhash, summer 2004. 


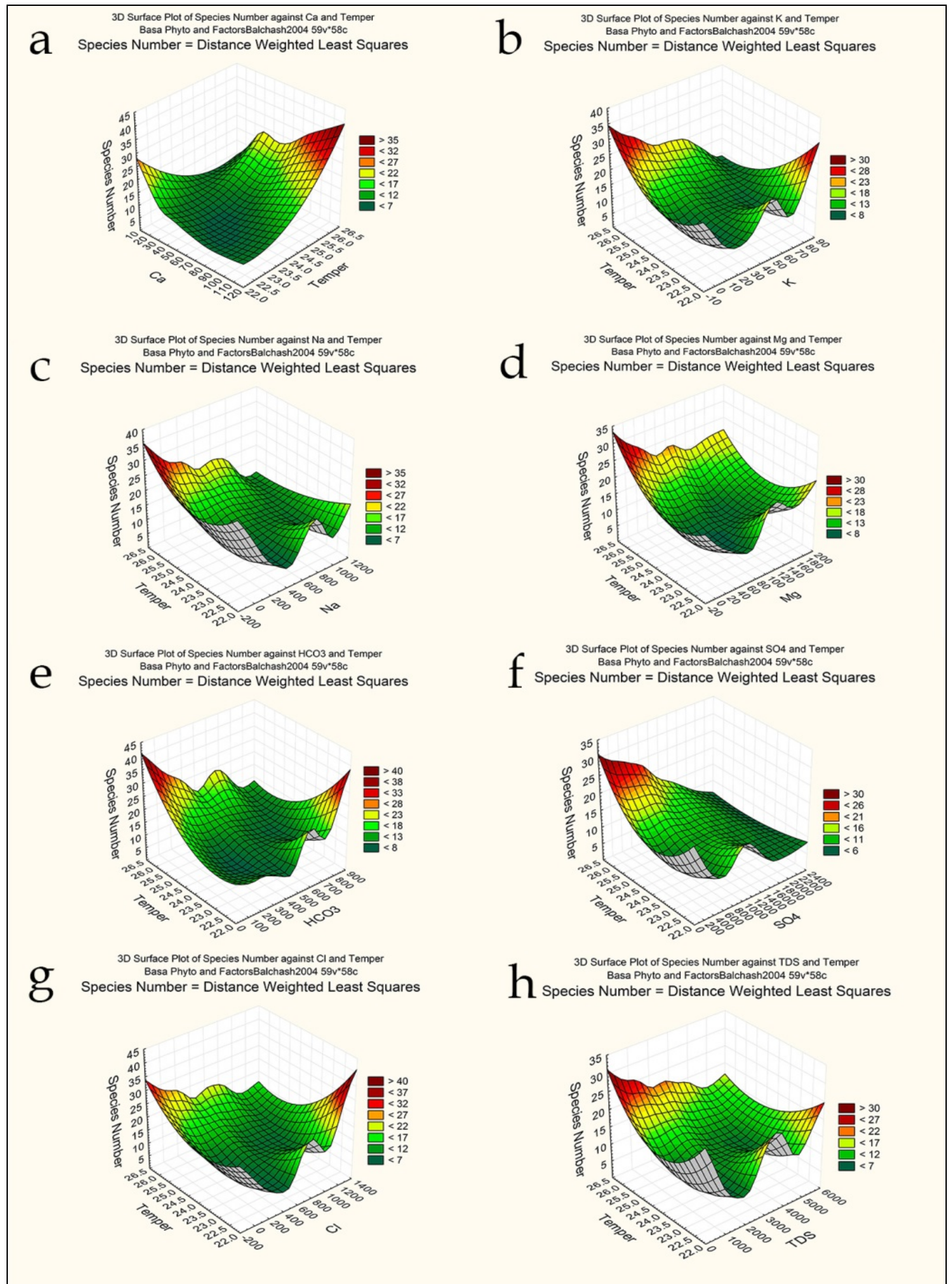

Figure 8: Spatial distribution of species richness of phytoplankton depending on the ion composition and total dissolved solids (TDS) in the water of Lake Balkhash, summer 2004. 


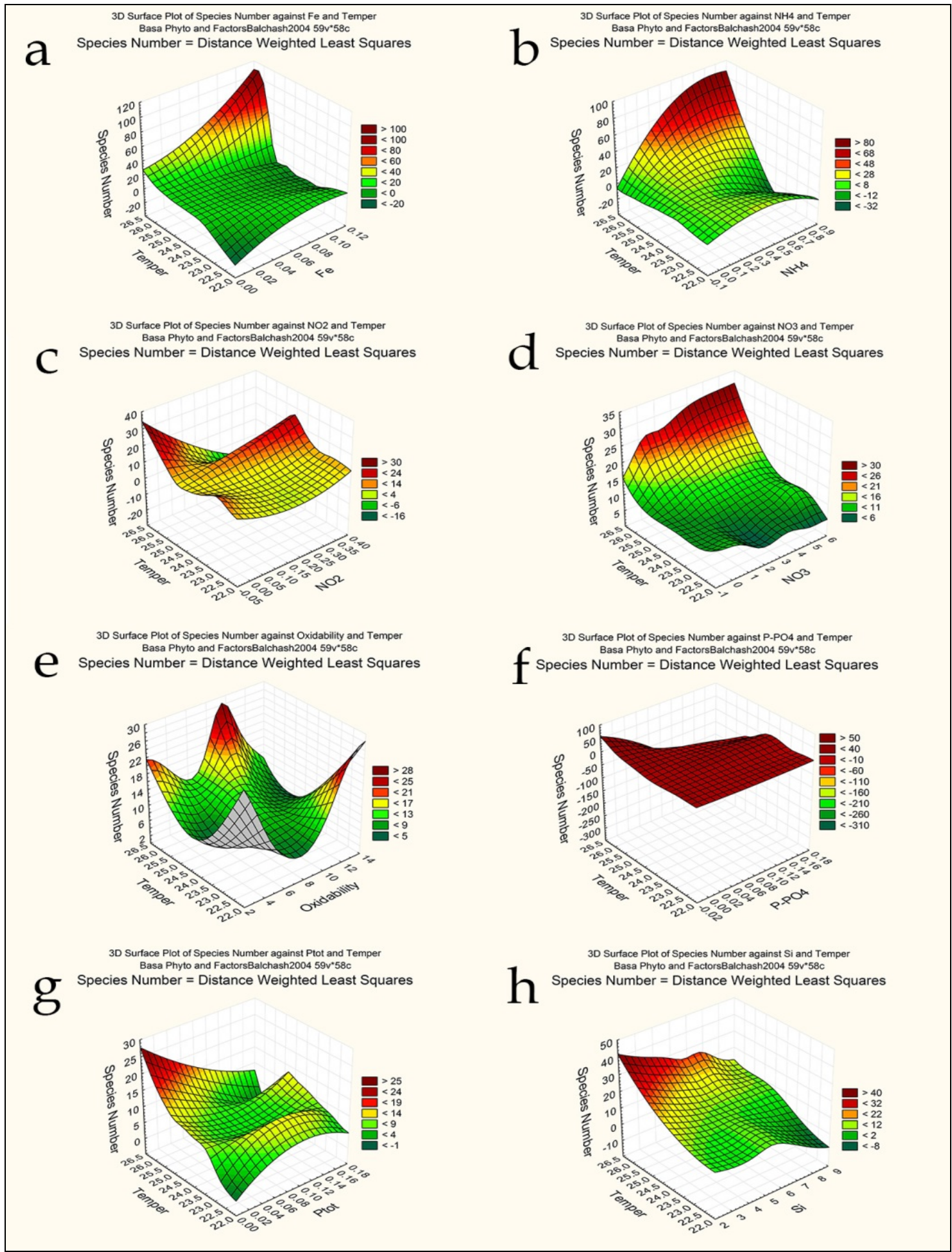

Figure 9: Spatial distribution of species richness of phytoplankton depending on the content of biogenic elements and easily oxidized organic matter in the water of Lake Balkhash, summer 2004. 


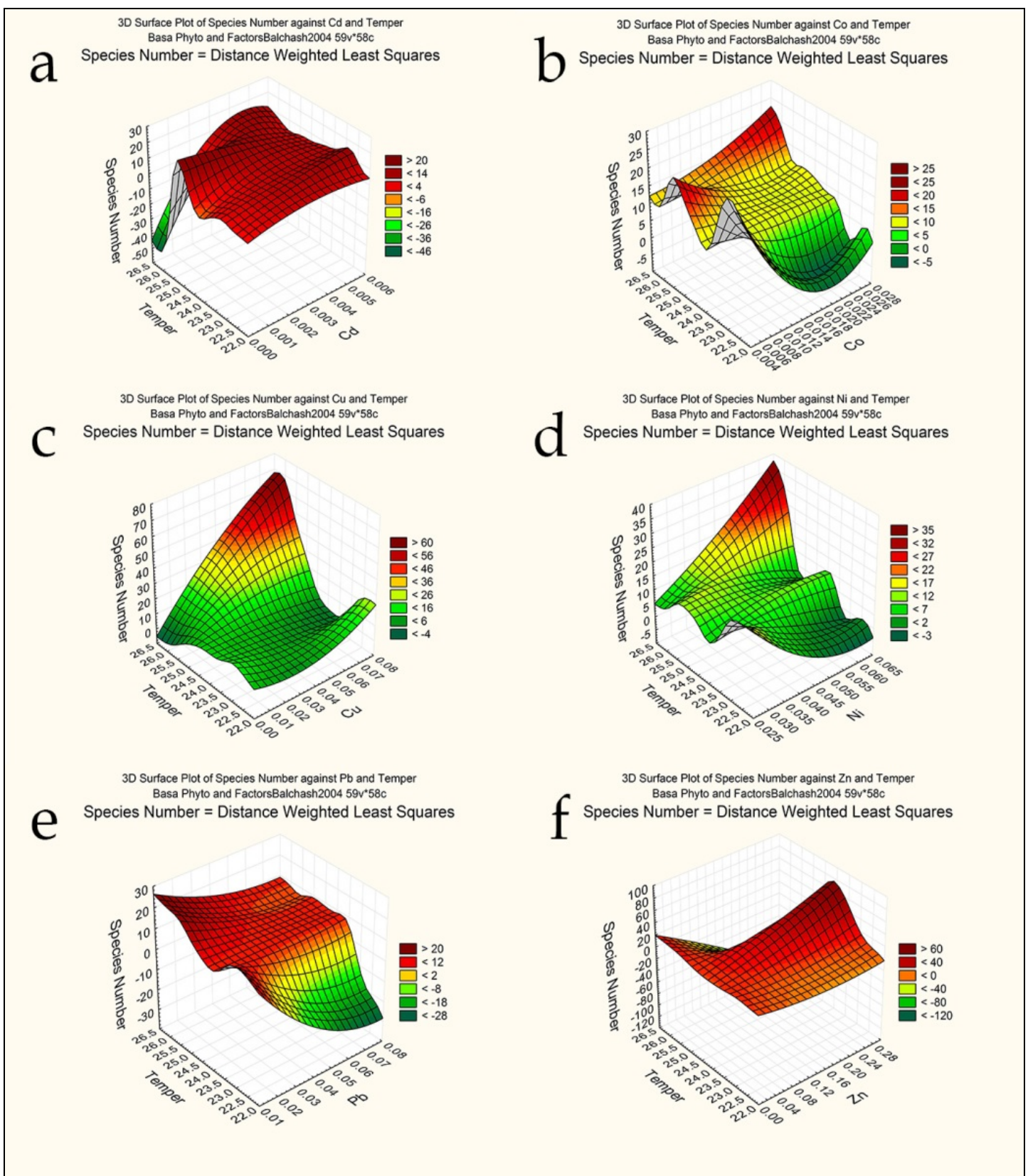

Figure 10: Spatial distribution of species richness of phytoplankton depending on the content of biogenic elements and easily oxidized organic matter in the water of Lake Balkhash, summer 2004. 

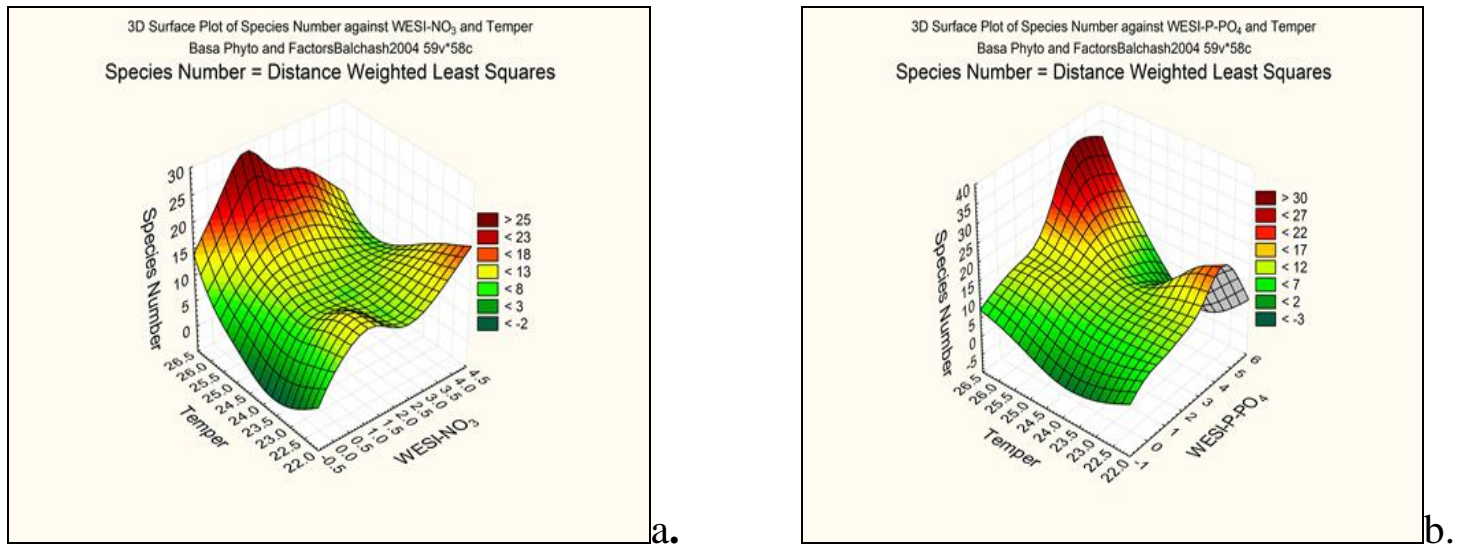

Figure 11a, b: Spatial distribution of species richness of phytoplankton in the gradient of total toxic pollution of Lake Balkhash in summer 2004.

Reduction of the total toxic pollution, expressed by the WESI-NO $\mathrm{N}_{3}$ index, stimulated the phytoplankton growth in species richness in the high temperature zone and, to a lesser extent, in the less heated areas of the lake (Fig. 11a). The most richest algal communities were represented at the maximum values of WESI-P-PO ${ }_{4}$ in the high-temperature zone also (Fig. 11b).

\section{DISCUSSION}

The phytoplankton of lake Balkhash was comprised of 91 species, with a variety of green, diatoms and cyanobacteria, in the summer of 2004. The species composition of the phytoplankton underwent changes in the hydrochemical regions of the lake, with an increase in the cyanobacteria species number and a decrease in the number of species of euglenoids, chrysophytes and dinophytes algae, as a response to a change in the ionic composition of water in the direction from west to east.

The species richness of phytoplankton communities was clearly traced in the salt gradient for water bodies in some regions (Barinova et al., 2009, 2011, 2015; Klymiuk et al., 2014; Bilous et al., 2016). The non-parametric correlation analysis results and 3d Surface Plots revealed a more complex character of the relationship of species richness of algae with hydrochemical conditions in lake Balkhash. The lack of a clear connection between TDS and the total species richness of phytoplankton is associated with a different reaction of algae to the salt composition of the water. The number of species of Cyanobacteria and Chrysophyta increased in the gradient of salinity or concentrations of individual ions positively associated with TDS, whereas the species richness of Euglenophyta and Dinophyta was decreased. The chemical composition of the water did not exert any significant influence on Charophyta and Chlorophyta species. Other environmental parameters also contributed to the variability of the phytoplankton species richness, the most important of which were the temperature and overgrowing of the water area by macrophytes. Spatial distribution maps and $3 d$ Surface Plots revealed an increase in the phytoplankton species richness with statistically weak connections in warmed shallow zones and macrophyte overgrowth. As shown by the analysis of reference data, a lower diversity of phytoplankton (Muylaert et al., 2006) is observed in the thickets of macrophytes in the humid zone reservoirs, as compared to the open areas, due to the high abundance of large plankton invertebrates eating algae (Pieczy'nska et al., 1999). The previously noted positive relationship between 
macrophytes and the number of phytoplankton species (Barinova and Krupa, 2017) is due to the fact that on the overgrowing areas of the arid zone water bodies, the role of small species in zooplankton, mainly rotifers (Krupa, 2012) are increased, which does not have a controlling effect on algae. Along with the temperature, phosphorus and nitrogen are the most important elements controlling the development of planktonic algae (Goncharov, 2007; Tolotti et al., 2012; Mingli et al., 2014). As the temperature and loading of nutrients rise, a gradual loss of the biological diversity of the aquatic ecosystem takes place (Elliott et al., 2006).

The important role of temperature, despite the relatively small amplitude of its oscillations, was traced when assessing the influence of all environmental parameters on the planktonic algae of Balkhash Lake. The same environmental indicator could have a different effect on the species richness of algae in the zone of relatively low $\left(22.5-23.0^{\circ} \mathrm{C}\right)$ and high temperatures $\left(25.0-26.0^{\circ} \mathrm{C}\right)$. Algal communities showed an almost linear increase in the number of species in the gradient of iron, ammonium, nitrates, and calcium at the maximum temperature. Unfavourable conditions for algae were formed with an increase in TDS, high concentrations of potassium, sodium, sulphates, and chlorides in warmed areas of the lake, while magnesium did not affect the species richness of phytoplankton. The variability of the number of species under relatively low temperatures was nonlinear in the gradient of potassium, sodium, and TDS, and had a second, less pronounced peak in the gradient of carbonates and chlorides. We did not find a direct correlation of the species richness in communities with phosphates, but the positive values of the WESI-P-PO ${ }_{4}$ index indicated a sufficient amount of phosphate in the lake. Thus, the dual nature of the relationship between species richness in algal communities and environmental parameters was traced, and it increased with increasing temperature in the nutrient gradient, but under conditions of minimum values of TDS and concentrations of the main ions. The positive effect of temperature on the number of species of planktonic algae is revealed with even a small gradient of this factor in the conditions of Balkhash Lake. Taking into account the literature data (Elliott et al., 2006), with a further increase in water temperature, one can expect a decrease in the species richness of phytoplankton that is an important prognostic conclusion in the future as it relates to global warming.

While maintaining the leading role of the temperature factor, 3d Surface Plots have revealed a complex, but weakly expressed, character of the dependence of the species richness of algae with heavy metals. This may be due to the increased content of dissolved solids in Balkhash Lake water, which, along with the alkaline reaction of water, contribute to reducing the toxic properties of heavy metals by finding the latter in an insoluble form (Nikanorov and Zhulidov, 1991). The obtained results with the new methods used showed that statistically significant, but weak, relationships can indicate a very complex character of the spatial variability of biological variables in the gradient of environment factors. One of the methods for detecting such nonlinear dependences is 3d Surface Plots construction, the use of which has made it possible to describe the variability of the phytoplankton species richness quite realistically with the hydrophysical, hydrochemical and toxicological variables of lake Balkhash. 


\section{CONCLUSIONS}

Nonparametric correlation analysis revealed a weakly, but statistically significant, relationship between the phytoplankton species richness and the environmental variables of lake Balkhash. This is due to the complex nature of the spatial variability of phytoplankton in the gradient of environmental factors, which is clearly demonstrated by three-dimensional graphs. The stimulating effect of macrophytes on the species richness of plankton algae is shown. The absence of a connection between the total species richness of phytoplankton and TDS is associated with a different reaction of algae to the salt composition of the water. The number of species of Cyanobacteria and Chrysophyta was increased, whereas Euglenophyta and Dinophyta were decreased in the gradient of salinity and concentrations of individual ions. The chemical composition of the water had no significant effect on Charophyta and Chlorophyta species. The important role of the temperature factor was traced when we assessed the influence of all environmental variables on the planktonic algae of Balkhash Lake. The same environmental variable caused different variability in the species richness of algae in the low $\left(22.5-23.0^{\circ} \mathrm{C}\right)$ and high temperature $\left(25.0-26.0^{\circ} \mathrm{C}\right)$ ranges. At maximum temperatures, the number of species of algae increased linearly in the gradient of iron, ammonium, nitrates, calcium, and decreased with TDS, high concentrations of potassium, sodium, sulphates, and chlorides, and throughout the magnesium content range. The variability of the number of species was non-linear in the gradient of potassium, sodium, and TDS, and had a second, less pronounced peak in the gradient of carbonates and chlorides under low-temperature conditions. Thus, the dual nature of the relationship between the species richness of algal communities and environmental variables was traced in its gradient in environment as species richness increased with increasing temperature in the nutrient gradient, but with a decrease in TDS and the main ions in water. With an increased content of heavy metals in lake Balkhash, they did not have a significant effect on the species richness of algae. This is due to the increased content of dissolved solids in Balkhash Lake and the alkaline reaction of water.

\section{ACKNOWLEDGEMENTS}

The work was carried out partly under the project number 1846/ГФ4 Г.2015-Г2016 for Committee of Science, Ministry of Education and Science, Republic of Kazakhstan "Development of the methods for controlling the ecological state of water bodies in Kazakhstan", "Study of the modern hydroecological state of fishery water reservoirs and development of biological justifications for the purposefulness and priority of fishery reclamation for conservation and enhancement of the fishery potential of the reservoir" as well as partly supported by the Israeli Ministry of Absorption. 


\section{REFERENCES}

1. Abrosov V. N., 1973 - Lake Balkhash, Leningrad, Russia, Science, 181. (in Russian)

2. Akhmetova N. I., 1986 - The abstract of the dissertation of the candidate of biological sciences, Leningrad, Russia, Botanical Institute named after N. L. Komarova, 25. (in Russian)

3. Barinova S. and Krupa E., 2017 - Bioindication of Ecological State and Water Quality by Phytoplankton in the Shardara Reservoir, Kazakhstan, Environment and Ecology Research, 5, 73-92.

4. Barinova S. S., Medvedeva L. A. and Anissimova O. V., 2006 - Diversity of algal indicators in environmental assessment, Tel Aviv, Pilies Studio, 498. (in Russian)

5. Barinova S. S., Klochenko P. D. and Belous Y. P., 2015 - Algae as Indicators of the Ecological State of Water Bodies: Methods and Prospects, Hydrobiological Journal, 51, 6, 3-21.

6. Barinova S. S., Bragina T. M. and Nevo E., 2009 - Algal species diversity of arid region lakes in Kazakhstan and Israel, Community Ecology, 10, 1, 7-16.

7. Barinova S. S., Nevo E. and Bragina T. M., 2011 - Ecological assessment of wetland ecosystems of northern Kazakhstan on the basis of hydrochemistry and algal biodiversity, Acta Botanica Croatica, 70, 2, 215-244.

8. Bilous O. P., Barinova S. S., Ivanova N. O. and Huliaieva O. A., 2016 - The use of phytoplankton as an indicator of internal hydrodynamics of a large seaside reservoir-case of the Sasyk Reservoir, Ukraine, Ecohydrology and Hydrobiology, 16, 160-174.

9. Elliott J. A., Jones I. D. and Thackeray S. J., 2006 - Testing the sensitivity of phytoplankton communities to changes in water temperature and nutrient load, in a temperate lake, Hydrobiologia, 559, 401-411.

10. Fokina A. S., 1982 - The present state of phytoplankton in the Balkhash Lake, in Forecast of the integrated and rational use of natural resources, their protection and prospects for the development of the productive forces of the Balkhash Lake basin, in the period until 1990-2000, Part 2, Alma-Ata, Kazakhstan: Science of KazSSR, 137-140. (in Russian)

11. Fomin G. S., 1995 - Water, control of chemical, bacterial and radiation safety according to international standards, Moscow, Russia: NGO “Alternative”, 618. (in Russian)

12. Gollerbach M. M., Kossinskaya E. K. and Polyansky V. I., 1953 - Key to freshwater algae of USSR, 2, Blue-green algae, Moscow, 654. (in Russian)

13. Goncharov A. V., 2007 - Comparison of Reservoirs in the Moskva-Vazuza water system in terms of phytoplankton abundance and eutrophication degree, Water Resources, 34, 1, 70-74.

14. Kiselev I. A., 1956 - Methods of study of plankton, in Life of freshwaters of the USSR, 4, Moscow, Leningrad, Russia: USSR Academy of Sciences, 183-265. (in Russian)

15. Klymiuk V., Barinova S. and Lyalyuk N., 2014 - Diversity and ecology of algal communities from the regional landscape park "Slavyansky Resort”, Ukraine, Research and Reviews: Journal of Botanical Science, 3, 2, 9-26.

16. Krupa E., Slyvinskiy G. and Barinova S., 2014 - The effect of climatic factors on the long-term dynamics of aquatic ecosystem of the Balkhash Lake (Kazakhstan, Central Asia), Advanced Studies in Biology, 6, 3, 115-136.

17. Krupa E. G., 2012 - Zooplankton of limnetic and running water ecosystems in Kazakhstan, Structure, forming patterns, Saarbrücken: Palmarium Academic Publishing, 346. (in Russian)

18. Kudekov T. K. (ed.), 2002 - The modern ecological state of the basin of Lake Balkhash, Almaty, Kazakhstan: Kaganat, 386. (in Russian)

19. Mazurov A. K., 2005 - Metallogenic zoning of Kazakhstan, Proceedings of Tomsk Polytechnic University, 308, 4, 33-39. (in Russian)

20. Mingli Y., Cuixia Z. H., Zengjie J., Shujin G. and Jun S., 2014 - Seasonal Variations in phytoplankton Community Structure in the Sanggou, Ailian, and Lidao Bays, Journal of Ocean University of China (Oceanic and Coastal Sea Research), 13, 6, 1012-1024. 
21. Moshkova N. A. and Gollerbach M. M., 1986 - Key to freshwater algae USSR, 10, 1, Green algae, Class Ulothrichophyceae, Moscow, Russia, Science, 361. (in Russian)

22. Muylaert K., Declerck S., Van Wichelen J., De Meester L. and Vyverma W., 2006 - An evaluation of the role of daphnids in controlling phytoplankton biomass in clear water versus turbid shallow lakes, Limnologica, 36, 69-78.

23. Nikanorov A. M. and Zhulidov A. V., 1991 - Biomonitoring of metals in freshwater ecosystems, Leningrad, Russia: Gidrometeoizdat, 144. (in Russian)

24. Novakovsky A. B., 2004 - Abilities and base principles of program module "GRAPHS", Scientific Reports of Komi Scientific Center, Ural Division of the Russian Academy of Sciences, 27, 1-28.

25. Palamar-Mordvintseva G. M., 1982 - Key to freshwater algae USSR, 11, 2, Green algae, Class Conjugatophyceae, Desmidiaceae (2), Moscow, Russia, Science, 621. (in Russian)

26. Pieczy’nska E., Kołodziejczyk A. and Rybak J. I., 1999 - The responses of littoral invertebrates to eutrophication-linked changes in plant communities, Hydrobiologia, 39, 9-21.

27. Ponomareva L. P., Shaukharbaeva D. S. and Lopareva T. Y., 2005 - Hydrochemical variables and phytoplankton as trophy indicators of the lake Balkhash and Ily River's reservoirs, in Fisheries research in the Republic of Kazakhstan, Almaty, Kazakhstan: Kaganat, 366-376.

28. Popova T. G., 1955 - Key to freshwater algae USSR, 7, Euglenophyta, Moscow, Russia, Science, 213. (in Russian)

29. Samakova A. B. (ed.), 2003 - Problems of hydroecological stability in the basin of Lake Balkhash, Almaty, Kazakhstan: Kaganat, 584.

30. Semenova A. D. (ed.), 1977 - Guideline for chemical analysis of surface water, Leningrad, Russia: Gidrometeoizdat, 541. (in Russian)

31. Tarasov M. N., 1961 - Hydrochemistry of Balkhash Lake, Moscow, Russia, Academy of Sciences of the USSR, 233. (in Russian)

32. Tolotti M., Manca M., Angeli N., Morabito G., Thaler B., Rott E. and Stuchlik E., 2012 Temperature modulated effects of nutrients on phytoplankton changes in a mountain lake, Hydrobiologia, 698, 61-75.

33. Vorobyeva N. B., Tyutenkov S. K., Sadukasova R. E. and Fokina A. S., 1982 - The current state and prospects for the development of the fodder base for fish in the Balkhash Lake depending on the level regime, in Forecast of the integrated and rational use of natural resources, their protection and prospects for the development of the productive forces of the Lake Basin, Balkhash in the period until 1990-2000, Part 2, Alma-Ata, Kazakhstan, Science of KazSSR, 129-132. (in Russian)

34. Zabelina M. M., Kiselev I. A., Proshkina-Lavrenko A. I. and Sheshukova V. S., 1951 - Key to freshwater algae USSR, 4, Diatoms, Moscow, 622. (in Russian) 